\title{
Comparison of Some Physicochemical Properties of Locust Bean Seeds Gum Extracted by Acid and Water Pre-Treatments
}

\author{
Neslihan Eda Kıvrak ${ }^{1}$, Buket Aşkın², Erdoğan Küçüköner ${ }^{1 *}$ \\ ${ }^{1}$ Department of Food Engineering, Suleyman Demirel University, Isparta, Turkey \\ ${ }^{2}$ Department of Food Engineering, Kırklareli University, Kırklareli, Turkey \\ Email: ${ }^{*}$ erdogankucukoner@sdu.edu.tr
}

Received 23 January 2015; accepted 10 February 2015; published 13 February 2015

Copyright (C) 2015 by authors and Scientific Research Publishing Inc.

This work is licensed under the Creative Commons Attribution International License (CC BY). http://creativecommons.org/licenses/by/4.0/

(c) () Op Open Access

\begin{abstract}
In this research, locust bean gums were removed from seeds with different extraction methods and some physicochemical properties were analyzed for gums and also locust beans. Three different extractions were treated at different temperatures and durations of sulfuric acid $\mathrm{CH}_{2} \mathrm{SO}_{4}$, $60 \%)$ solution, hydrochloric acid $(\mathrm{HCl}, 30 \%)$ solution and boiling water. Following dehulling and drying processes, seeds were milled and locust bean gums (LBG) were obtained eventually. The color values, moisture, protein, ash, sugar, $\mathrm{pH}$, total acidity, soluble solids content, foreign particulates, acid insoluble ash contents and viscosity curves were compared for all samples. The results exhibited that the highest ash $(1.94 \%)$ and protein $(6.65 \%)$ contents were determined by water extraction gum, the highest acid-insoluble ash (3.58\%) and foreign particulates $(44.17 \%)$ contents were determined by $\mathrm{HCl}$ extraction gum. The lowest protein $(5.01 \%)$, acid insoluble ash $(1.29 \%)$, the foreign particulates $(34.99 \%)$ and the highest viscosity value $(533.9 \mathrm{mPas})$ were found from $\mathrm{H}_{2} \mathrm{SO}_{4}$ extraction gum. The results of investigation also showed that the $\mathrm{H}_{2} \mathrm{SO}_{4}$ extraction method was found to be more appropriate than $\mathrm{HCl}$ and water extraction methods to obtain a good quality gum.
\end{abstract}

\section{Keywords}

Extraction Methods, Gum, Locust Bean, Physicochemical Properties, Viscosity

\footnotetext{
${ }^{*}$ Corresponding author.
}

How to cite this paper: Kıvrak, N.E., Aşkın, B. and Küçüköner, E. (2015) Comparison of Some Physicochemical Properties of Locust Bean Seeds Gum Extracted by Acid and Water Pre-Treatments. Food and Nutrition Sciences, 6, 278-286. 


\section{Introduction}

The locust bean gum (LBG) has obtained by crushing the endosperm of seeds from fruit pod of the carob tree (Cerationia siliqua L.) grown in Mediterranean regions [1]. The locust bean gum plays an important role in the rheological properties of food products if it can be obtained in pre form [2]. LBG is an effective way to use as a stabilizer, thickener, gelling agent and fat replacer for different food products due to its natural image, the neutral taste and the viscosity and also it provides which is a white or creamish white, odorless powder [3]. Furthermore, LBG has a positive impact on the protein stability, crystal structure of ice cream and it has reducing effect for syneresis in fruit and dairy applications [4] [5].

The seed has three main constituents: husk (30\% - 33\%), endosperm (42\% - 46\%) and germ (23\% - 25\%) and also they are covered with a tight-fitting brown coat [6]. LBG is obtained from endosperm and so the first stage of the gum extraction involves removal of the seed hull. For the gum extraction, these coats can be removed by the different thermo-mechanical or chemical treatments. The seeds are split lengthwise and the endosperm is separated from the germ [7]. After the isolation process, endosperms are grounded and sifted for obtain to the locust bean gum (LBG) or carob gum [5] [7] [8]. Different acids, alcohols and water can be used for extraction process and each one has different challenges and advantages for gum quality and economical value. It is the most important point for the process must avoid changes on the chemical and physical properties [7] [9].

A high purity LBG generally contains moisture $10 \%-13 \%$, protein $5 \%$, ash $1 \%$, fiber $1 \%$ and galactomannan 80\% - 85\% [1]. LBG has high-molecular-weight and describes chemically as galactomannan, depending on the chemical structures consisting of $\beta$-(1-4)-D-mannopyranosyl backbone and $\alpha$-(1-6)-D-galactopyranosyl simple units are linked as a side chain [10] [11]. LBG typically has a mannose to galactose (M/G) approximately ratio of about 4 which among to the major commercially available galactomannans, furthermore carob galoctomannan has the lowest galactose content with about 20\% [12]. The different galactomannans can be distinguished by their mannose-to-galactose ratio and their molecular weight [7] [12]. The molecular size and the structural properties affect to the solubility and also check to the rheological properties [13].

The aim of this study was to extract locust bean gum with three different methods from the carob seeds and to compare these extracts.

\section{Experimental}

\subsection{Reagent and Materials}

Locust bean is a species of flowering evergreen shrub or tree in the pea family, Fabaceae. It is widely cultivated for its edible pods, and as an ornamental tree in gardens. Locust bean fruits were used to obtain LBGs in this research belongs to Isparta region and they were purchased from a company selling dried nuts and fruits. This carob fruits were cut with scissors for obtain to the carob seeds. The physical properties were measured and the length and thickness were determined ranging between 6.0 and $10.8 \mathrm{~mm}$ and 2.0 and $4.9 \mathrm{~mm}$, respectively.

Three different methods preferred to extraction of the carob seeds, with acid and water. All reagents used for liquid chromatography were of HPLC grade and obtained from Merck (Darmstad, Germany). All other reagents were of analytical grade and obtained from Merck (Darmstad, Germany).

\subsection{Extraction Methods}

Sulfuric acid extraction (LBG1): Whole carob seeds (100 g) were kept in $120 \mathrm{ml}$ of $60 \%, \mathrm{H}_{2} \mathrm{SO}_{4}$ (Merck, $\mathrm{K} 38346531$ ) solution at $65^{\circ} \mathrm{C}$ for $2 \mathrm{~h}$. Seeds were deported from the solution, the coat was removed by washing and rubbing operation in water and on the metallic sieve. The uncoated seeds were dried at $100^{\circ} \mathrm{C}$ for 30 min and crushed (10 seeds dehusked/3s) with a laboratory mill to separate the two endosperms and the germ. The endosperms were grinded (IKA A11 basic, Germany) and sifted $(0.125 \mathrm{~mm})$ to obtain LBG flour [7]. The sulfuric acid extraction procedure was shown in Figure 1.

Hydrochloric acid extraction (LBG2): Whole carob seeds (100 g) were kept in $400 \mathrm{ml}$ of 30\%, HCl (Merck, $\mathrm{K} 36508317$ ) solution at $75^{\circ} \mathrm{C}$ for $1 \mathrm{~h}$. Seeds were removed from the solution, the coat was removed by washing and rubbing operation in water and on the metallic sieve. The uncoated seeds were kept in $700 \mathrm{ml}$ water for $24 \mathrm{~h}$ at ambient temperature. At the end of this time, water was filtered and endosperms were separated manually from the germ. The endosperms were dried at $30^{\circ} \mathrm{C}$ for $24 \mathrm{~h}$ and were grinded (IKA A11 basic, Germany) and sifted $(0.125 \mathrm{~mm})$ to obtain LBG flour [14]. The hydrochloric acid extraction procedure was shown in Figure 2. 


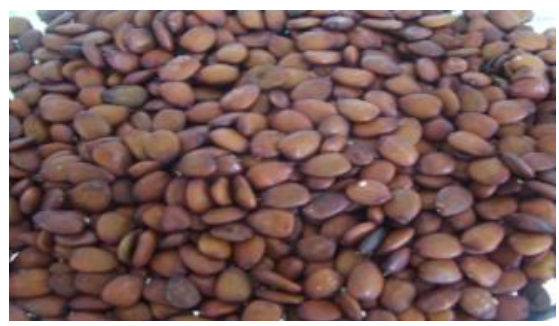

Non-extracted Locust bean seeds

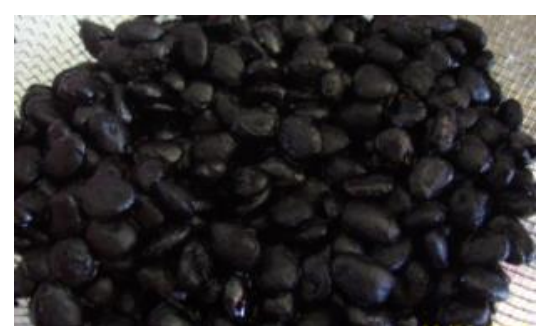

L. beans have extracted by $\mathrm{H}_{2} \mathrm{SO}_{4}$

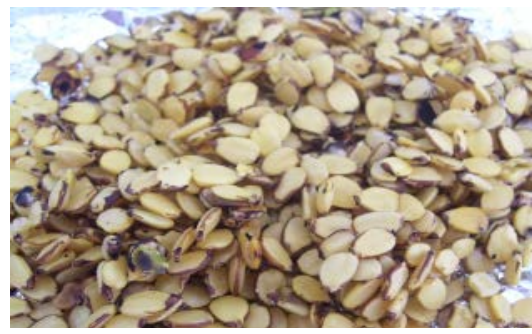

Dried L. beans after $\mathrm{H}_{2} \mathrm{SO}_{4}$ extraction

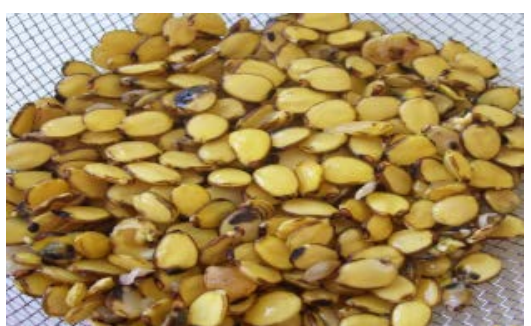

L. beans without coats were removed by $\mathrm{H}_{2} \mathrm{SO}_{4}$

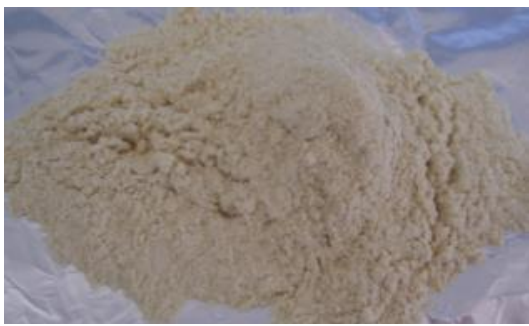

L. bean gum produced by $\mathrm{H}_{2} \mathrm{SO}_{4}$ extraction

Figure 1. The sulfuric acid extraction procedure.

Water extraction (LBG3): Whole carob seeds (100 g) were kept in $800 \mathrm{ml}$ of boiling water at $100^{\circ} \mathrm{C}$ for $1 \mathrm{~h}$. Seeds were removed from the water, washed and the tegument broken and divided by hand into the coat, endosperm and germ. Then the germ was separated from the endosperms which were dried at $100^{\circ} \mathrm{C}$ for $1 \mathrm{~h}$. The endosperms were grinded (IKA A11 basic, Germany) and sifted $(0.125 \mathrm{~mm})$ to obtain LBG flour [15]. The water extraction procedure was shown in Figure 3.

\subsection{Physicochemical Analysis}

\subsubsection{Physical Analysis}

The color values were measured on LBG samples. L, a, b color values of the samples were measured using a colorimeter (Konica Minolta CR 400, Japan). The L value represents the lightness, a value indicates red and green colors and $b$ value indicates yellow and blue colors. Chroma (C) representing the color intensity and $h^{\circ}$ for the hue angle were calculated by the using a and $b$ values the following equations [16].

$$
\begin{aligned}
& \mathrm{C}=\left[(\mathrm{a})^{2}+(\mathrm{b})^{2}\right]^{1 / 2} \\
& \mathrm{~h}^{\circ}=\arctan (\mathrm{b} / \mathrm{a}) \cdot(180 / \pi)
\end{aligned}
$$

\subsubsection{Chemical Analysis}

The moisture content of the carob gums was determined after drying the samples in an oven at $105^{\circ} \mathrm{C}$ until constant weight (Mettler Toledo, AB204, Sweden). The ash content of the carob gums (4 g) were determined by burning the samples at $550^{\circ} \mathrm{C}$ for $12 \mathrm{~h}$ (Nüve MF, 106).

The protein contents of the gums were estimated using the Kjeldahl assay and were converted to protein content using the conversion factor 6.25 [17]. The total sugar contents of the seeds and gums were determined as a 


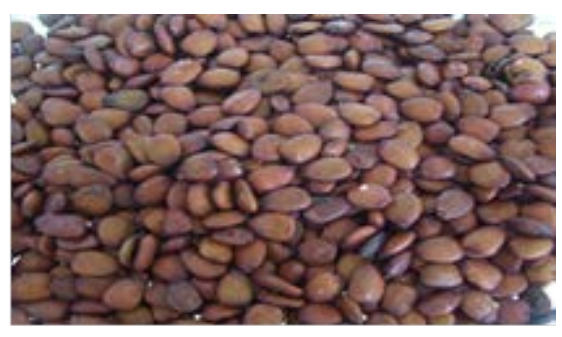

Non-extracted Locust bean seeds

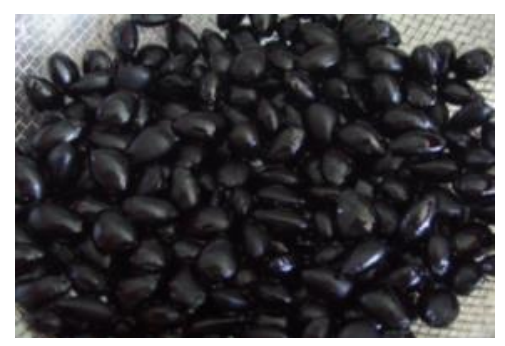

L. beans have extracted by $\mathrm{HCl}$

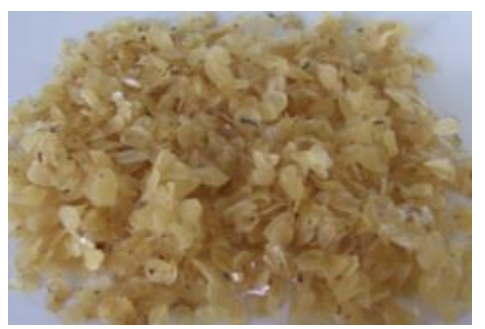

Dried L. beans after HCl extraction

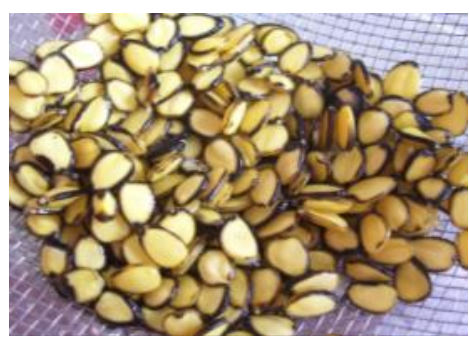

L. beans without coats were removed by $\mathrm{HCl}$

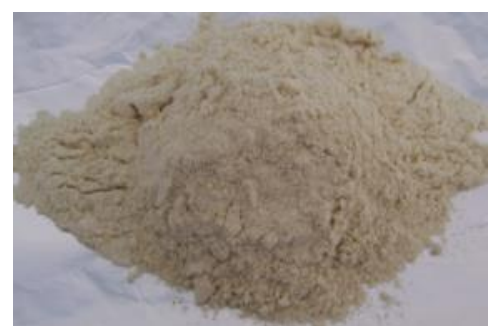

L. bean gum produced by $\mathrm{HCl}$ extraction

Figure 2. The hydrochloric acid extraction procedure.

spectroscopically. Samples $(0.1 \mathrm{~g})$ were kept in $100 \mathrm{ml}$ of boiling water at $95^{\circ} \mathrm{C}$ for $3 \mathrm{~h}$. The solution containing the samples was filtered from the coarse filter paper and volume was completed to $100 \mathrm{ml}$. And then $1 \mathrm{ml} \mathrm{sam}-$ ple solution was mixed with $2 \mathrm{ml}$ anthron reagent $\left(0.2 \mathrm{~g}\right.$ anthron suspended in $\left.100 \mathrm{ml} 96 \%, \mathrm{H}_{2} \mathrm{SO}_{4}\right)$ and heated for $15 \mathrm{~min}$ at $95^{\circ} \mathrm{C}$ in a boiling water bath. After cooling and centrifuging, sugar content was determined at 540 $\mathrm{nm}(\mu \mathrm{g} / \mathrm{g})(\mathrm{T} 70+\mathrm{UV} / \mathrm{VIS}$ Spectrometer, PG Instruments Ltd., England) [18].

\subsubsection{Gum Solution Analysis}

The $\mathrm{pH}$ value of the gums was measured with the $\mathrm{pH}$ meter (Hana, HI $221 \mathrm{pH}$ Meter, USA Gum solutions (1\%, $\mathrm{w} / \mathrm{v})$ ) were prepared in distilled water at ambient temperature. The total acidity of the gums was determined by titrimetric method. Gum solutions $(1 \%, \mathrm{w} / \mathrm{v})$ were prepared in distilled water at ambient temperature and the titrant was $0.01 \mathrm{~mol} \cdot \mathrm{L}^{-1} \mathrm{NaOH}$ solution. The soluble solids of the gums were determined with ABBE refractometer (Bellingham-Stanley, 60/70 Abbe Refractometer, England). Gum solutions (1\%, w/v) were prepared in distilled water at ambient temperature.

The acid-insoluble ash of the gums was determined from previously obtained ashes. On the crucibles containing the ash, $10 \mathrm{ml}$ of $10 \% \mathrm{HCl}$ solution was added and heated for $15 \mathrm{~min}$ at $95^{\circ} \mathrm{C}$ in a boiling water bath. Crucible content was filtered from ash-free filter paper and filter paper washed with hot water chloride ions until there is no in the permeate. The presence of chloride ions were checked with silver nitrate solution $(17 \mathrm{~g} / \mathrm{L}$, Fluka, 85228). Filter papers were ignited for $30 \mathrm{~min}$ at $625^{\circ} \mathrm{C}$. After cooling and weighting in precision balance, acid-insoluble ash content was determined as \% by weigh [19].

The particulates were determined as percent value by dry weigh. Gum solutions $(1 \%$, w/v) were prepared in distilled water at ambient temperature and mixed with mixer at high speed for $2 \mathrm{~min}$. They were heated at $70^{\circ} \mathrm{C}$ in a boiling water bath for $1 \mathrm{~h}$ while being stirred at low speed. After cooling and centrifugation at $6000 \mathrm{~g}$ for 30 min, the supernatant was decanted. Samples were oven dried overnight at $105^{\circ} \mathrm{C}$ [14] [20]. 


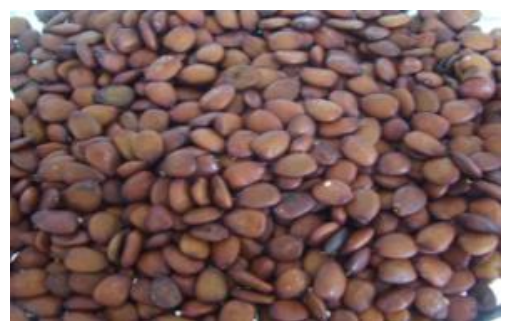

Non-extracted Locust bean seeds

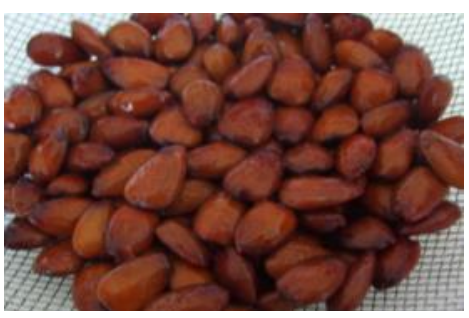

L. beans have extracted by water

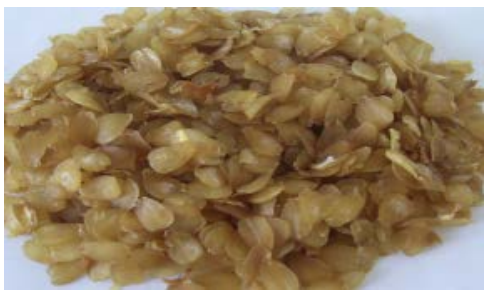

Dried L. beans after water extraction

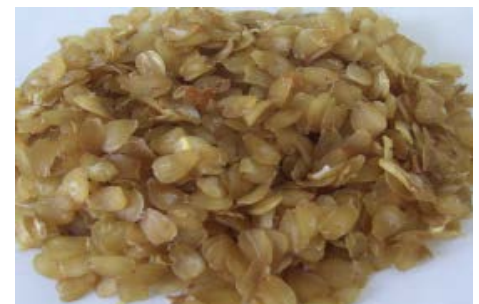

L. beans without coats were removed by water

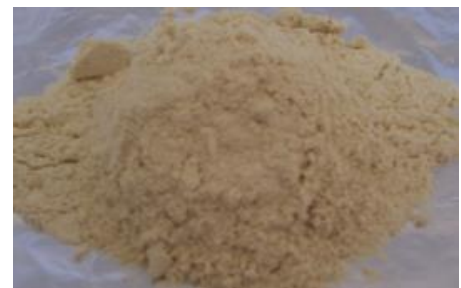

L. bean gum produced by water extraction

Figure 3. The water extraction procedure.

The viscosity was determined by the viscometer (Brookfield DV-II Pro Viscometer, England). Gum solutions $\left(1 \%\right.$, w/v) were prepared by adding $600 \mathrm{ml} 100 \mathrm{mM}$ sodium phosphate buffer, $\mathrm{pH} 7.0$, at $75^{\circ} \mathrm{C}$, using a high speed mixer for $2 \mathrm{~min}$. The samples were left overnight at ambient temperature to hydrate. They were briefly stirred with a magnetic stirrer to ensure homogeneity prior to measurement [20]. Viscosity of samples was measured using the LV-4 bit at $100 \mathrm{rpm}$, at $25^{\circ} \mathrm{C}$, at intervals 30 seconds for 3 minutes [14]. Graph of time-viscosity was plotted with the viscosity values.

\subsection{Statistical Analysis}

The findings of the analysis, the SPSS 17 statistical software package using the 0.05 significance level according to Duncan-ANOVA multiple comparison test evaluated the border. During the analysis, descriptive statistics such as the average, maximum value, minimum value, standard deviation, standard error were determined. Differences between groups were identified at the 0.05 significance level.

\section{Results and Discussions}

\subsection{Physical Analysis}

In all extraction assays easily broke to the coat but there were differences for separating the germ and endosperm. So, the coat was easily broken and separated easily with blender for 3 seconds in sulfuric acid extraction. In all extraction assays easily broke to the coat but there were differences for separating the germ and endosperm. So, the coat was easily broken and separated easily with blender for 3 seconds in sulfuric acid extraction. The color values of carob seeds and gums obtained from different extraction methods are also shown in Table 1.

In determining the color of foods CIE-Lab system is used mostly. In this system $\mathrm{L}$ value represents brightness, a value represents green-red color and b value represents blue-yellow color [21]. In addition, this system L, a and $\mathrm{b}$ values of $\mathrm{x}$ and $\mathrm{y}$ axes are shown, using these values the color angle (hue) are calculated around the $\mathrm{x}$ and 
Table 1. The color values for L, a, b and calculated properties of carob seeds and gums.

\begin{tabular}{cccccc}
\hline Sample & $\mathrm{L}$ & $\mathrm{a}$ & $\mathrm{b}$ & Hue $(\mathrm{h})$ & Croma (C) \\
\hline LBG1 & $86.27^{\mathrm{a}} \pm 4.06$ & $0.22^{\mathrm{a}} \pm 0.15$ & $10.09^{\mathrm{a}} \pm 1.33$ & $88.73^{\mathrm{a}} \pm 0.83$ & $10.09^{\mathrm{a}} \pm 1.33$ \\
LBG2 & $80.55^{\mathrm{b}} \pm 4.52$ & $1.36^{\mathrm{b}} \pm 0.32$ & $12.60^{\mathrm{b}} \pm 1.25$ & $83.96^{\mathrm{b}} \pm 0.89$ & $12.67^{\mathrm{b}} \pm 1.28$ \\
LBG3 & $85.61^{\mathrm{a}} \pm 2.82$ & $-0.44^{\mathrm{c}} \pm 0.44$ & $11.52^{\mathrm{ab}} \pm 1.11$ & $92.35^{\mathrm{c}} \pm 2.40$ & $11.53^{\mathrm{ab}} \pm 1.09$ \\
\hline
\end{tabular}

*Means within a column followed by the same letter are not significantly different $(\mathrm{p}>0.05)$.

y axis $360^{\circ}$ angle is expressed. The angle values are positioned $0^{\circ}$ red, $90^{\circ}$ yellow, $180^{\circ}$ blue and $270^{\circ}$ green [22].

As seen in the results, the L values were available statistically significant difference between LBG1 - LBG3 and LBG2 ( $<$ 0.05). The L values of gums were lower than the seeds. The reason is that, colors of the gums were lighter than the seeds. According to the values of a and b, there were statistically significant difference between the findings of gum samples $(\mathrm{p}<0.05)$. The a values of gums were lower than seeds for the same reason of $\mathrm{L}$ values. The $\mathrm{b}$ values of gums were higher than seeds; this result show that gums color is the light yellow. As for the hue and chroma values were available statistically significant difference between gum samples $(p<0.05)$ because of the differences a and $b$ values.

\subsection{Chemical Composition of the Gums}

The chemical composition of the gums obtained from different extraction methods are shown in Table 2. In general results are quite similar each other in the literature [1] [7] [23]. Among these studies, in the LBGs the lowest protein content (1\%) was reported by Avallone et al. (1997) and the highest protein content (10.3\% 17.1\%) was reported by Kök (2007) [2] [23]. The ash and moisture results are similar with the given studies. Also, Dakia et al. (2008) reported to the sugar contents for two different LBG samples as 4.5\% and 6.8\% [7].

The ash and protein contents were reduced while the purification of LBGs from seeds because of eliminated practically all fat and fibre [1]. High range of the ash content obtained in seed may be caused by the coat and the germ mineral substances. Moreover, high protein content obtained from LBG3 compared to other LBGs may be due to a contamination by carob germ which contains high protein amount. About $5 \%$ the protein content of the crude gum is based on the natural presence of structural proteins and enzymes, but also a possible contamination with seed germ [7]. As for high sugar content obtained in LBG1 may be due to a contamination by seed coat or during the acid extraction to come distortion and then a piece of sugar to be free. The free sugar amount increase the presence of minor amount of rhamnose, arabinose, xylose and glucose could be attributed to a more complex polysaccharide composition or contamination by the seed coat [7]. The extraction endosperm from the seeds allows impurities in the commercially sold gum and obviously this has a direct impact on sugar composition [2].

Composition of the seed can change from growing conditions of carob fruit and tree, keeping conditions after the harvesting [1]. For this reason, there were some differences between studies due to using carob seeds from different regions.

\subsection{Gum Solution Results}

The some of gum solutions (1\%, w/v) properties as particulates (P), soluble solids (Ss), total acidity (Ta), pH and acid-insoluble ash (Aia) of gums are also shown in Table 3.

The acid-insoluble matter refers to the presence of acid-insoluble impurities in gums such as metals. This amount indicates impurity substances in gums so this property is unwanted. The crude and purified locust bean gum from seven areas of the north and center of Tunisia were analyzed for acid-insoluble matter by Bouzouita et al. (2007) [1]. The cured LBG from different regions had 5.38\% - 8.60\% acid-insoluble matter. Our results were similar to those reported by Bouzouita et al. (2007) [1].

The other important property of LBGs is contained low particulates. The particulates remained insoluble impurities after heating to $70^{\circ} \mathrm{C}$. The presence of particulate negatively affects the quality of the gum and its functional properties to viscosity and gelling. Kök (2007) analyzed for particulate of higher quality refined locust bean gum (rLBG) and lower quality crude locust bean gum (cLBG) samples [2]. The rLBG had 0\% particulate 
Table 2. Some chemical properties of gums.

\begin{tabular}{ccccc}
\hline & Moisture (\%) & Ash (\%) & Protein (\%) & Sugar (\%) \\
\hline LBG1 & $11.30^{\mathrm{a}} \pm 0.27$ & $1.02^{\mathrm{a}} \pm 0.05$ & $5.01^{\mathrm{a}} \pm 0.64$ & $2.33^{\mathrm{a}} \pm 0.13$ \\
LBG2 & $09.75^{\mathrm{b}} \pm 0.27$ & $0.84^{\mathrm{b}} \pm 0.03$ & $5.22^{\mathrm{a}} \pm 0.91$ & $1.99^{\mathrm{b}} \pm 0.34$ \\
LBG3 & $08.11^{\mathrm{c}} \pm 1.62$ & $1.94^{\mathrm{c}} \pm 0.17$ & $6.65^{\mathrm{b}} \pm 0.15$ & $1.74^{\mathrm{c}} \pm 0.16$ \\
\hline
\end{tabular}

*Means within a column followed by the same letter are not significantly different ( $\mathrm{p}>0.05)$.

Table 3. Some properties of gum solutions.

\begin{tabular}{|c|c|c|c|c|c|}
\hline & Aia (\%) & $\mathrm{p}(\%)$ & Ss ( $\left.{ }^{\circ} b x\right)$ & Тa (\%) & $\mathrm{pH}$ \\
\hline LBG1 & $1.29^{b} \pm 0.19$ & $34.99^{b} \pm 0.84$ & $0.93^{\mathrm{a}} \pm 0.06$ & $0.0034^{\mathrm{b}} \pm 0.001$ & $5.63^{a} \pm 0.03$ \\
\hline LBG2 & $3.58^{\mathrm{a}} \pm 0.15$ & $44.17^{\mathrm{a}} \pm 0.80$ & $0.57^{\mathrm{b}} \pm 0.06$ & $0.0053^{\mathrm{a}} \pm 0.001$ & $5.15^{b} \pm 0.02$ \\
\hline LBG3 & $1.36^{\mathrm{b}} \pm 0.37$ & $35.62^{\mathrm{b}} \pm 0.90$ & $0.73^{\mathrm{c}} \pm 0.06$ & $0.0026^{\mathrm{b}} \pm 0.002$ & $6.52^{\mathrm{C}} \pm 0.02$ \\
\hline
\end{tabular}

${ }^{*}$ Means within a column followed by the same letter are not significantly different $(\mathrm{p}>0.05)$; ${ }^{* *}$ Total acidity was given anhydrous citric acid.

and the cLBG had 7\% - 38\% particulates. In our study, crude locust bean gums were derived so our results (34.99\% - 44.17\%) were similar to those reported by Kök (2007) [2].

Another important property of LBGs is brix value indicates soluble solids in water. This value consists of sugars firstly such as glucose, fructose and sucrose, in addition to various organic acids such as citric acid, malic acid. In this study, soluble solids results were consistent with sugar content predictably.

The total acidity and $\mathrm{pH}$ value are important factors to be obtained. The $\mathrm{pH}$ value is an expression of hydrogen ion activity and the lower the $\mathrm{pH}$ value increases the acidity of the environment. The total acidity and $\mathrm{pH}$ value are statistically significant differences $(\mathrm{p}<0.05)$ in LBG samples. In the literature, there is no evidence of the amount of total acidity, $\mathrm{pH}$ and soluble solids of gum solutions.

\subsection{Viscosity}

Viscosity of LBG solutions prepared by adding $600 \mathrm{ml}$ and $100 \mathrm{mM}$ sodium phosphate buffer, $\mathrm{pH} 7.0$, at $75^{\circ} \mathrm{C}$ are shown in Figure 4.

Viscosity of LBG solutions were measured for 3 minutes 30 seconds intervals and the graphics are drawn at Figure 4. As shown the graphic, viscosity values were statistically significant differences $(p<0.05)$ between the LBG samples.

Viscosity of LBG2 and LBG3 are significant differences at the first and the last moments, but the rapidity of increase in viscosity for these samples were similar. Viscosity of the LBG1 and the rapidity of viscosity increases were found to be higher than other gum solutions. The viscosity of LBG3 was found lower than the other samples. The reason is that, used boiling water during the extraction process of LBG3 had a negative effect on the viscosity [7] [24]. Our viscosity results were quite similar to each other studies in the literature. Biliaderis et al. (2000) purified locust bean gums from twelve different regions of Greece and measured viscosity of 1\% (w/v) LBG solutions [1]. During the measurement, they used Ubbelohde No 1 Capillary Viscometer and found viscosity values between $0.4-1.4$ Pas at $25^{\circ} \mathrm{C}$ and $100 \mathrm{rpm}$. Also Demirtaş (2007) obtained LBG by soaking seeds in solutions of various chemicals of different concentrations [14]. Viscosity of $1 \%$ solutions were measured with the Brookfield DV-II + Pro Viscometer at $25^{\circ} \mathrm{C}$ and $100 \mathrm{rpm}$ and found that between 0.296 to 2.482 Pas. At the other study, Dakia et al. (2008) compared the viscosity of two different LBGs applied water and acid extraction process [7]. They prepared $1 \%$ solutions at $10 \mathrm{~s}^{-1}$ and $300 \mathrm{~s}^{-1}$ shear rates at $25^{\circ} \mathrm{C}$ and $80^{\circ} \mathrm{C}$ and they measured viscosity of this LBG with the Rotovisco Haake RV20 Rotational Viscometer. At the same concentration, the water extraction gum solution had a lower viscosity than the acid extraction gum solution at low and high temperatures. At the same time, the viscosity of gums decreased when the shear rate increased. At the same shear rate the viscosity of gums increased with increasing temperature. These results show that viscosities of gum solutions due to temperature and shear rate. 


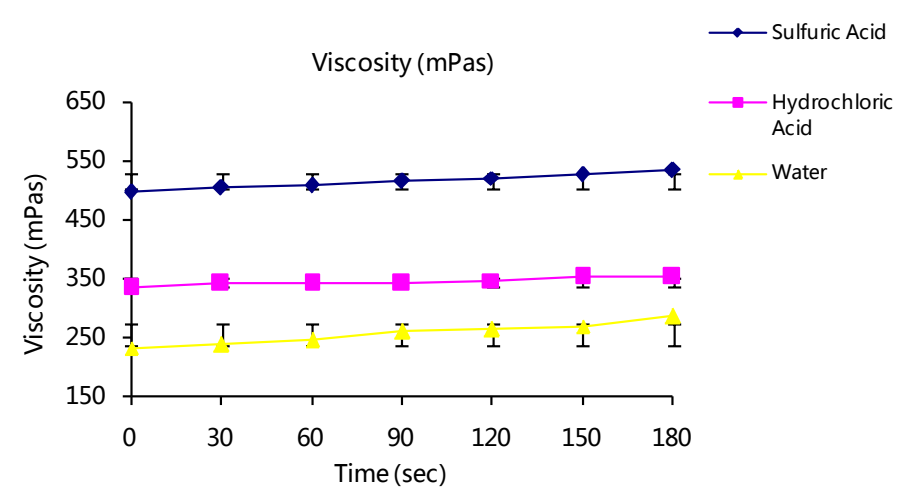

Figure 4. Viscosity values of LBG solutions (mPas).

\section{Conclusions}

In this study, locust bean gums were produced from carob seeds with three different extraction methods. Some physical and chemical properties of these LBGs were analyzed and investigated the effect of extraction methods on the LBGs.

For these methods, $\mathrm{H}_{2} \mathrm{SO}_{4}$ extraction fails in seed dehulling process. The reason for this, concentration and amount of the solution are thought to be insufficient. As for the $\mathrm{HCl}$ extraction, method is used successfully in the seed dehulling process. However; this method has a disadvantage about samples amounts which are used for high content. Water extraction method is the most successful method for seed dehulling process. At the same time, maximum range of gum is obtained in this method. But more effort and consuming time are needed for used human power.

For obtaining high quality locust bean gum, the ash, protein, acid insoluble ash, particulates values should be low and the viscosity should be high. When these properties are examined, water and $\mathrm{HCl}$ extraction gums have highly undesirable characteristics and $\mathrm{H}_{2} \mathrm{SO}_{4}$ extraction gum is found within the limits of the appropriate. The most important quality criterion of gums is the viscosity. According to the viscosity results, the high viscosity value is obtained from the $\mathrm{H}_{2} \mathrm{SO}_{4}$ extraction. For all these reasons, the results of investigation study showed that the $\mathrm{H}_{2} \mathrm{SO}_{4}$ extraction method was found to be more appropriate than $\mathrm{HCl}$ and water extraction methods to obtain a good quality gum.

\section{Acknowledgements}

We thank to "Suleyman Demirel University Unit of Scientific Research Project Commission" for funding of the research and "Directorate of Konya Provincial Control Laboratory" for their support to methodology.

\section{References}

[1] Bouzouita, N., Khaldi, A., Zgoulli, S., Chebil, L., Chekki, R., Chaabouni, M.M. and Thonart, P. (2007) The Analysis of Crude and Purified Locust Bean Gum: A Comparison of Samples from Different Carob Tree Populations in Tunisia. Food Chemistry, 101, 1508-1515. http://dx.doi.org/10.1016/j.foodchem.2006.03.056

[2] Kök, M.Ş. (2007) A Comparative Study on the Compositions of Crude and Refined Locust Bean Gum: In Relation to Rheological Properties. Carbohydrate Polymers, 70, 68-76. http://dx.doi.org/10.1016/j.carbpol.2007.03.003

[3] Edwards, H.G.M., Falk, M.J., Sibley, M.G., Alvarez-Benedi, J. and Rull, F. (1998) FT-Raman Spectroscopy of Gums of Technological Significance. Spectrochimica Acta Part A: Molecular and Biomolecular Spectroscopy, 54, 903-920. http://dx.doi.org/10.1016/S1386-1425(98)00018-3

[4] Biliaderis, C.G., Lazaridou, A. and Izydorczyk, M.S. (2000) Structural Characteristics and Rheological Properties of Locust Bean Galactomannans: A Comparison of Samples from Different Carob Tree Populations. Journal of the Science of Food and Agriculture, 81, 68-75.

[5] Pollard, M.A., Kelly, R., Wahl, C., Fischer, P., Windhab, E., Eder, B. and Amado, R. (2007) Investigation of Equilibrium Solubility of a Carob Galactomannan. Food Hydrocolloids, 21, 683-692. http://dx.doi.org/10.1016/j.foodhyd.2006.08.010

[6] Neukom, H. (1988) Carob Bean Gum: Properties and Applications. Proceedings of the II International Carob Sympo- 
sium, 551-555.

[7] Dakia, P.A., Blecker, C., Robert, C., Wathelet, B. and Paquot, M. (2008) Composition and Physicochemical Properties of Locust Bean Gum Extracted from Whole Seeds by Acid or Water Dehulling Pre-Treatment. Food Hydrocolloids, 22, 807-818. http://dx.doi.org/10.1016/j.foodhyd.2007.03.007

[8] Nussinovitch, A. (1997) Gum Technology in the Food and Other Industries.

[9] Dakia, P.A., Wathelet, B. and Paquot, M. (2007) Isolation and Chemical Evaluation of Carob (Ceratonia siliqua L.) Seed Germ. Food Chemistry, 102, 1368-1374. http://dx.doi.org/10.1016/j.foodchem.2006.05.059

[10] Azero, E.G., Lopes, L.L. and Andrade, C.T. (1997) Extraction and Solution Properties of the Galactomannan from the Seeds of Cassia javanica L. Polymer Bulletin, 39, 621-625. http://dx.doi.org/10.1007/s002890050194

[11] Anonymous (2003) Turkish Food Legislation. Türk Gida Mevzuatı.

[12] Picout, D.R., Ross-Murphy, S.B., Jumel, K. and Harding, S.E. (2002) Pressure Cell Assisted Solution Characterization of Polysaccharides. 2. Locust Bean Gum and Tara Gum. Biomacromolecules, 3, 761-767. http://dx.doi.org/10.1021/bm025517c

[13] Lazaridou, A., Biliaderis, C.G. and Izydorczyk, M.S. (2000) Structural Characteristics and Rheological Properties of Locust Bean Galactomannans: A Comparison of Samples from Different Carob Tree Populations. Journal of the Science of Food and Agriculture, 81, 68-75. http://dx.doi.org/10.1002/1097-0010(20010101)81:1<68::AID-JSFA780>3.0.CO;2-G

[14] Demirtaş, Ö. (2007) Investigation of Gum Productıon Possibilities from Locust Bean (Ceratonia siliqua) seeds. Keçiboynuzu (Ceratonia siliqua) çekirdeklerinden gam üretim yollarının araştırılması. Master Thesis, Çukurova University, Institute of Science, Çukurova Üniversitesi, Fen Bilimleri Enstitüsü, Yüksek Lisans Tezi, Adana.

[15] Tous, J., Romero, A., Hermoso, J.F., Ninot, A., Plana, J. and Batlle, I. (2009) Agronomic and Commercial Performance of four Spanish Carob Cultivars. HorlTechonology, 19, 465-470.

[16] Ersus, S. and Yurdagel, U. (2007) Microencapsulation of Anthocyanin Pigments of Black Carrot (Daucus carota L.) by Spray Drier. Journal of Food Engineering, 80, 805-812. http://dx.doi.org/10.1016/j.jfoodeng.2006.07.009

[17] Cemeroğlu, B. (2010) Food Analysis. 70.

[18] Praznik, W., Mundigler, N., Kogler, A., Wollerdorfer, M., Pelzi, B. and Huber, A. (1999) Molecular Background of Technological Properties of Selected Starches. Starch, 51, 197-211. http://dx.doi.org/10.1002/(SICI)1521-379X(199906)51:6<197::AID-STAR197>3.0.CO;2-K

[19] Anonymous (2006) Analysis Work Instructions for Acid Insoluble Ash Determination of Plum Nectar. Erik Nektarında Asitte Çözünmeyen Kül Miktarı Tayini Analiz Çalışma Talimatı, Konya İl Kontrol Laboratuar Müdürlüğü.

[20] Kök, M.Ş., Hill, S.E. and Mitchell, J.R. (1999) Analysis Work Instructions for Acid Insoluble Ash Determination of Plum Nectar. Food Hydrocolloids, 13, 535-542. http://dx.doi.org/10.1016/S0268-005X(99)00040-5

[21] Y1lmaz, İ. (2002) Selçuk University, Symposium of 30th Year in Geodesy and Photogrammetry Engineering Education. Selçuk Üniversitesi Jeodezi ve Fotogrametri Mühendisliği Öğretiminde 30. Y1l Sempozyumu, 340-350.

[22] Erbay, B. (2004) Evaluation of Color Changes in Fresh Cut Apple Slices with Machine Vision System. Taze kesilmiş elma dilimlerinde renk değişiminin bilgisayarlı görüntüleme sistemi ile incelenmesi. Master Thesis, Suleyman Demirel Universiy, Institute of Science, Isparta.

[23] Avallone, R., Plessi, M., Baraldi, M. and Monzani, A. (1997) Determination of Chemical Composition of Carob (Ceratonia siliqua): Protein, Fat, Carbohydrates, and Tannins. Journal of Food Composition and Analysis, 10, 166-172. http://dx.doi.org/10.1006/jfca.1997.0528

[24] Higiro, J., Herald, T.J., Alavi, S. and Bean, S. (2007) Rheological Study of Xanthan and Locust Bean Gum Interaction in Dilute Solution: Effect of Salt. Food Research International, 40, 435-447. http://dx.doi.org/10.1016/j.foodres.2006.02.002 
Scientific Research Publishing (SCIRP) is one of the largest Open Access journal publishers. It is currently publishing more than 200 open access, online, peer-reviewed journals covering a wide range of academic disciplines. SCIRP serves the worldwide academic communities and contributes to the progress and application of science with its publication.

Other selected journals from SCIRP are listed as below. Submit your manuscript to us via either submit@scirp.org or Online Submission Portal.
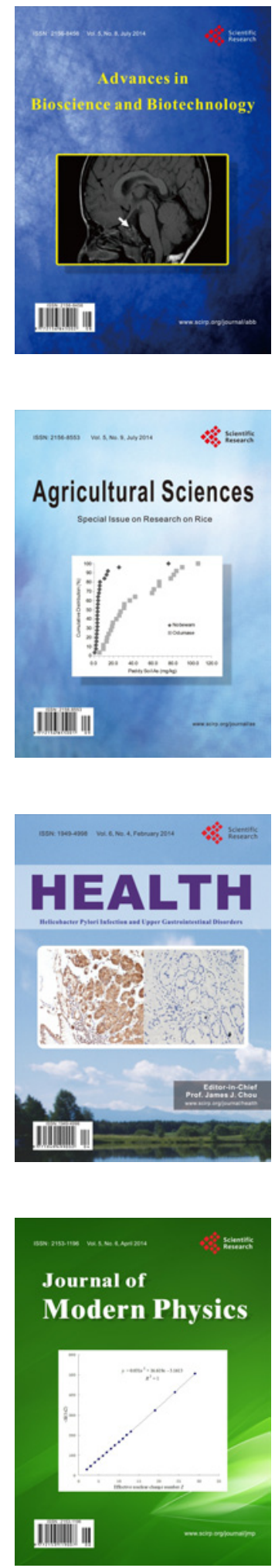
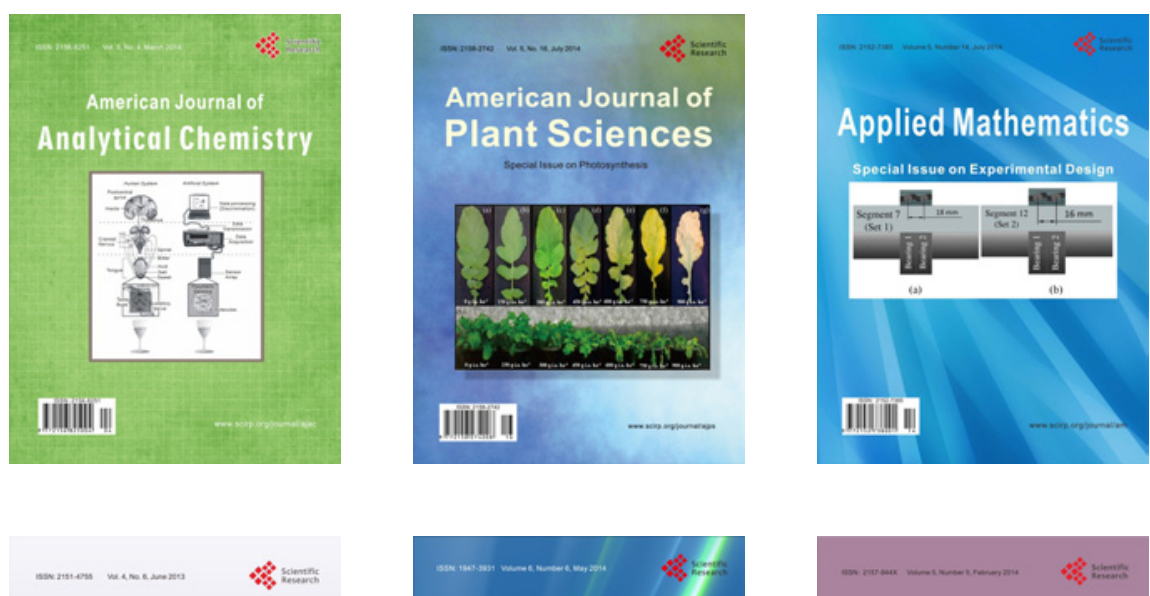

Creative Education
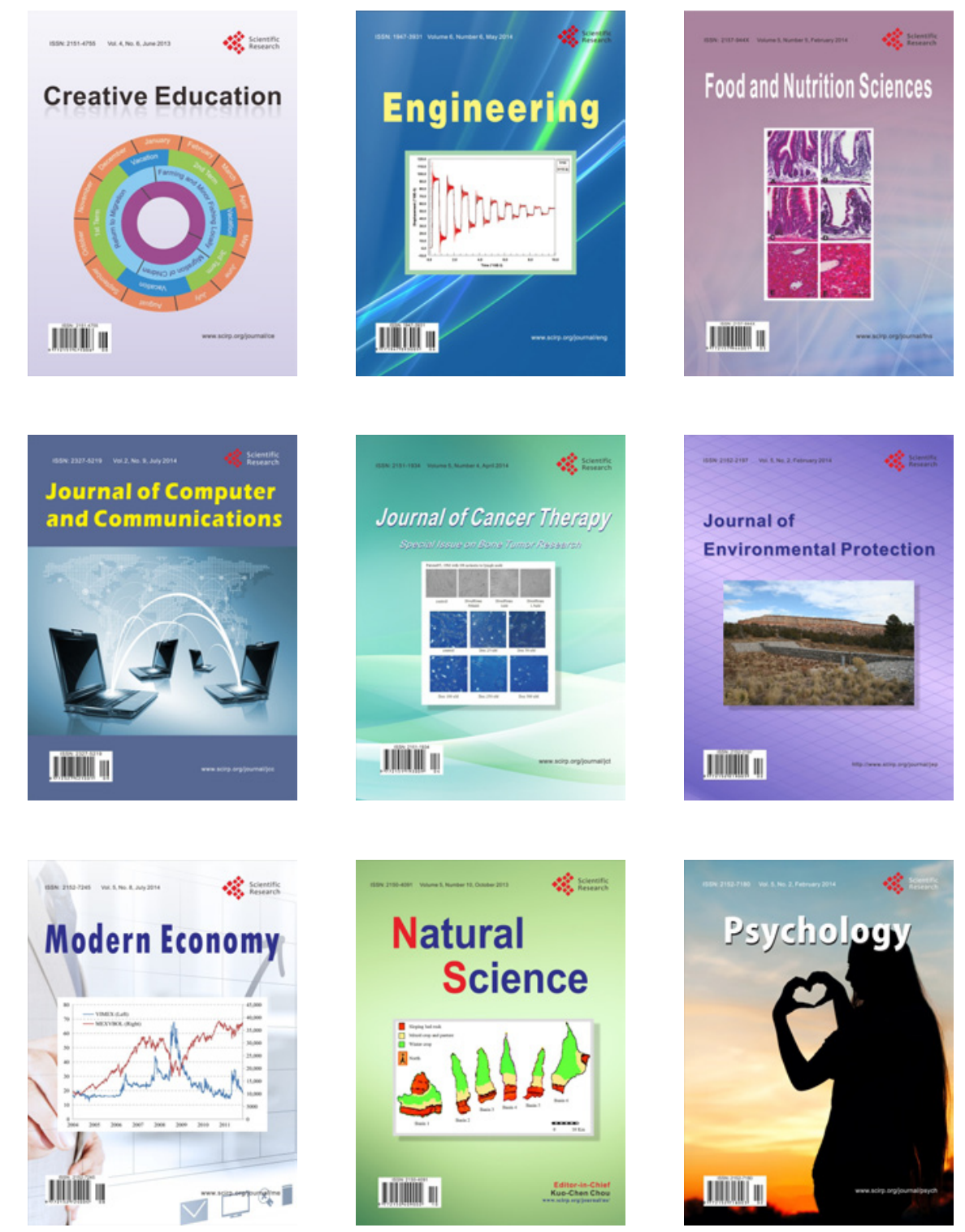